\title{
Technological and Productive Density in Sectoral Innovation Systems:The Case of the Brazilian Aeronautics Industry
}

\author{
Marcio da Silveira Luz', Sergio Luiz Monteiro Salles-Filho²
}

\begin{abstract}
This article discusses whether a globally competitive high-tech firm is sustainable without being associated with a sufficiently dense sectoral innovation system. It focuses on Embraer and hence on the Brazilian aeronautics industry. Despite not benefiting from a highly subsidized process for technological and financial modernization, Embraer has become the world's third-ranking producer of commercial jets thanks to institutional innovations, especially in producing and managing contracts with suppliers and risk-sharing partners. The conclusion drawn is that the competitiveness of the Brazilian aircraft industry depends on the continuing supply of technology in international markets. Technological restrictions imposed for geopolitical reasons, or even for market constraints, could fatally undermine the strategy adopted by the company.
\end{abstract}

Keywords: Aeronautics industry; innovation systems; industrial organization; technological change.

\footnotetext{
'Researcher, Aerospace Science and Technology Department, DCTA ñ Brazilian Air Force Command. Division of Innovation ManagementDGI, Department of Aerospace Sciences and Technology - DCTA, Brazilian Air Force Command, Av. dos Astronautas 1947, Bairro Martim Cererí, S,,o JosĖ dos Campos, SP - 12 227-000 - phone 551939476634 Email:msluzsjc@gmail.com

2 Professor, Department of Scientific and Technological Policy ñ University of Campinas ñ UNICAMP, Departmente of Science and Technology Policy, Institute of Geosciences. University of Campinas, POBox 6I52, Campinas, SP - I3 $083-970$ - phone 55 I9 352 I 4555 Email: monteirosalles@gmail.com
} 


\section{Introduction}

Brazil's industrial matrix is sophisticated from the productive standpoint, but it emphasizes production more than value creation and appropriation. Production chains are strongly asymmetric with value chains, hence the scant value added. Sectoral innovation systems are mostly incomplete, lacking the points of greatest creativity, which are precisely those that add most value. Thus, national industrial policy has not yet left behind a manufacturing vision to adopt a value creation and appropriation one. Most of policymakers continue to focus on the idea that what matters is the "shop floor", regardless of how much value is added in production.

As a reflection of this structure, sectoral production and innovation systems are still deficient with regard to value creation and appropriation. Among few exceptions, as in the case of the aeronautics industry, Brazil has strongly increased its share of the world market, with Embraer achieving third place in 2007 behind the giants Boeing and EADS, but ahead of Bombardier, its closest competitor. In this sense, Embraer is a unique phenomenon in Brazil: aircraft manufacturing is the only high-tech industry of all the globally competitive sectors in Brazil today.

A closer analysis of the sectoral innovation system (SIS) in Brazil's aeronautics industry, however, highlights a combination not seen anywhere else, between a strong company, Embraer, and a relatively weak production chain (small suppliers), partnering with a group of research institutions whose importance to the system varies greatly (Dagnino, 1993; Bernardes, 2000; Marques \& Oliveira, 2009).

In this sense Embraer can be considered an exception in the global aeronautics industry and in the recent trajectory of the Brazilian manufacturing sector. Three main competencies explain Embraer's recent success: outstanding capabilities in engineering design; excellence in assembly and systems integration; and contractual innovation, buying the required technology wherever it can be found.

The main purpose of this work is to present and discuss the formation of the Brazilian aircraft industry in light of the SIS concept, seeking conceptual and empirical elements that can help explain the company's recent success and predict possible future trajectories. In other words, in addition to describing and qualifying the Brazilian AISIS it also sets out to discuss the sustainability of the industry's recent trajectory, analyzing in particular the extent to which a complex sectoral system such as the aeronautics industry can maintain global competitiveness while buying mission-critical technology in the marketplace, without major internal R\&D efforts, and making relatively little use of typical government support, such as public-sector procurement, military orders, R\&D subsidies etc.

Thus the article addresses two key issues, one theoretical and the other factual. The theoretical issue relates to understanding and analyzing the sustainability of SIS in their territorial specificities.

The article has four sections besides this introduction. The next section presents and discusses the theoretical framework used to define sectoral production and innovation systems, pinpointing the most useful conceptual elements for an analysis of the characteristics and prospects of the Brazilian AISIS. The following section analyzes the main characteristics of the global aeronautics industry, emphasizing the Brazilian AISIS, its history, development, current makeup, value chain, investment in R\&D, and technological leadership by Embraer. Lastly, the article presents conclusions indicating that technological density needs to be developed for long-term sustainability and that productive density should be a consequence of strategic decisions to expand the local knowledge base, local R\&D, and local innovation.

\section{Sectoral Innovation Systems Subjects or Participants}

The innovation systems approach is particularly appropriate to explain the innovation process as a collective game in which various different and complementary components must interact so that new products and services can be created. In the case of the aeronautics industry, the idea of a dynamic combination of different actors to produce innovations is highly relevant, given the industry's productive, scientific, technological and organizational complexity.

Sectoral innovation systems (SIS) in the aeronautics industry can also be characterized as complex adaptive systems, in accordance with Hobday (1998), who notes that in some cases a project is begun without even 
prior knowledge of all the technology required to solve the problems involved, and this technology has to be developed during the course of the project.

Innovation systems can be understood as the structure and dynamics that enable the innovations of a given country, region or industry to be understood. With regard to coverage, innovation systems are usually classified as national, regional, local or sectoral (OECD, 1997). Particularization of the concept for the sectoral level was thoroughly developed by Malerba and collaborators (Malerba, 2002; 2004; Malerba \& Mani, 2009).

The sectoral innovation system model synthesizes and defines the core elements of innovation, their behavior, limits and interactions. It promotes a better understanding of the specific learning and innovation processes in any given sector. Thus it is a simultaneously simple and effective approach that facilitates the comprehension of complex aspects of innovation dynamics by enabling their components to be distinguished and analyzed in terms of their interrelationships, so that development policies can be formulated and implemented. Moreover, the model is appropriate for computer simulations to facilitate the comprehension of inputs, outputs and outcomes (Malerba, 2004).

Malerba (2002) detailed the concept of sectoral systems by breaking it down into seven basic elements: products; agents; knowledge and learning processes; basic technologies, inputs, demand, linkages and complementarities; interaction mechanisms between firms and non-firms; variation and selection processes; and institutions.

In analyzing the ways in which these elements of the system interrelate, Malerba (2002) argues that sectoral co-evolution is a process of interaction among technology, industrial structure and institution, basing this view on Nelson (1994) and Metcalfe (1998). He adds that it involves links between demand, knowledge base, learning processes and organization (firms and non-firms). By focusing on knowledge base and learning processes instead of industrial structure we can better understand the dynamics of knowledge, competencies and sectoral competitiveness with regard to market structure.

In the case of the global aeronautics industry, although it typically has a creative accumulation regime (largely owing to strongly path-dependent technology accumulation), aircraft manufacturers' ability to command the sectoral system of production and innovation is a matter of mutual dependency rather than hierarchy. Of course, giant firms such as Boeing and EADS have significant power of induction over technology and innovation in the sectoral system, but even they have to deal with other giant firms that supply aircraft parts and aeronautical systems. Thus there is a kind of balance between integrators and suppliers, determined by the greater or lesser power of induction wielded by the firms involved and by a close relationship between users and producers of technology (Lundvall, 1992; Bernardes, 2000).

The systems approach is useful when studying innovation organization and dynamics in countries, regions and sectors, precisely because it shows the composition and above all the interrelations between components (both the components and their interrelations are variable). Nelson (1990) shows that the most successful innovation systems are the best interrelated and coordinated, not necessarily the most complete. This is especially valid for sectoral innovation systems (see Malerba, 2002).

On the other hand, it must be acknowledged that certain types of industrial organization display similarities in their various innovation systems. Even in these systems, however, there may be organizational and institutional innovations (in contract management, for example) that change the structure in place so as to compensate for its deficiencies and fill any gaps in technical and scientific competencies using innovative managerial solutions. This is the point discussed below: production and technology densities may be more or less necessary to enhance a sector's global competitiveness, but what seems to be most important is the ability to build relationships, alongside the existence of flows of product and process technology offerings, which are decisive for success in a complex high-tech industry (Hobday et al., 2005).

The next section discusses the characteristics of aeronautics industry innovation systems on a global scale, particularly in terms of constitution and competition, with special emphasis on the Brazilian case. 


\section{The Aeronautics Industry Sectoral System}

This section presents a brief overview of the global aeronautics industry, followed by a more detailed outline of the profile and evolution of the Brazilian industry, highlighting its constitution, institutional composition, investment and characteristics according to the concepts relating to sectoral innovation systems discussed above.

\section{The global aeronautics industry}

The global aeronautics industry is highly concentrated at present. Formation of the Boeing and LockheedMartin conglomerates in the U.S., EADS, BAer and ATR in the European Union, and Bombardier in Canada resulted from major mergers and acquisitions designed to strengthen this strategically important sector financially and technologically. Governments openly contributed to the merger and acquisition (M\&A) process via funding in most cases. The companies involved were mostly set up by aviation pioneers, growing stronger during world war two and the cold war, especially thanks to the boom in defense procurements following the emergence of the militaryindustrial complex in the U.S. These contracts drove the development of technology frequently embodied in civilian applications.

According to OECD (1997) and Santos (2009), the overall characteristics and competitive dynamics of the aerospace industry make it one of the most important sectors in the productive structure of the advanced economies.

Thus the pattern of competition in this industry revolves around the continuous introduction of technological innovations and the conditions for financing innovation, which takes place continuously but gradually. Despite what has been said, the introduction of technological innovations even when incremental leads to the emergence of a new "dominant project" and a rupture of the prevalent technological paradigm. This new project soon becomes mandatory, and competing firms are obliged to adopt it or be forced out of the market. Cumulativeness and path dependence are strongly present in the sector (Dosi, 1988). As a result, the aerospace industry is characterized by a high level of technological dynamism, which contributes to permanent changes in its configuration (Ferreira, 2009).
The next subsection outlines the constitution of this system in Brazil, associating the historical elements of its formation with the sectoral system concepts discussed in the introductory section of this article.

\section{The Brazilian Aeronautics Industry Sectoral Innovation System (AISIS)}

The modern Brazilian aeronautics industry started with the Bandeirante plane which made its maiden flight on October 22, 1968. To produce it Embraer was incorporated on August 19, 1969, with the federal government owning $51 \%$ and the rest belonging to private investors. (Silva, 1998; Bertazzo, 2008).

In 197I, Embraer began making the Italian light attack jet and trainer Aermacchi MB 326, renamed Xavante, under license. In the late 1960s the agriculture ministry commissioned the Ipanema for agricultural use, mainly crop dusting. This aircraft made its maiden flight in 1970 and went into production in 1972 (I,000 units have now been produced). The Tucano (BEM-3I2), a military turboprop for pilot training, first flew in 198I. This plane and its light attack version, the Super Tucano (EMB-3I4), are both best-sellers (Silva, 1998; Bernardes, 2000; Forjaz, 2005; Bertazzo, 2008).

Embraer steadily acquired more competencies. After the Bandeirantes it launched the Xingu, a pressurized twin turboprop with the same wing and engine design but with a completely new fuselage. It then produced the Brasília (EMB-120), a high-performance twin turboprop commuter airliner for 30 passengers widely used by regional airlines in the U.S. and Europe, which acquired it in the 1980s and 1990s (Bernardes, 2000; Forjaz, 2005; Silva, 1998).

In 1982 Embraer began a partnership with Italian firms to design and build the AMX ground attack aircraft, a "simplified" version of the Panavia Tornado. This enabled Embraer to achieve a technological leap forward (Bernardes, 2000; Forjaz, 2005; Silva, 1998).

In late 1980s Embraer was hit by a dire financial crisis that shook the world and had especially severe effects for Brazil (the foreign debt crisis of 1982). By the beginning of the 1990s government decided to privatize the firm but was determined to transfer majority ownership to 
Brazilians. In 1992 Ozires Silva was invited to return as CEO and head the privatization process. Embraer was put up for auction in 1994 (Forjaz, 2005). The new controlling shareholders were pension funds with $40 \%$, Bozzano, Simonsen with $20 \%$, and a group of investors with a total of $20 \%$ comprising Dassault, EADS, Snecma and Thales Group. The Brazilian government, represented by the air force ministry, today a military command subordinated to the defense ministry, kept a golden share (Bernardes, 2000; Forjaz, 2005; Silva, 1998).

An extensive corporate restructuring program was implemented following privatization. The next step was the launch of the ERJ-I45 family of commercial jetliners for up to 50 passengers. This has been a success, selling I,000 aircraft by 2006. Fresh investment was then made to produce the Embraer 170/195 line of aircraft with between 70 and 120 seats, originally classified as E-Jets. These too have sold well. Embraer also markets Legacy and Phenom executive jets and is steadily growing its share of this market.

In 2006, to counterbalance the centrifugal force of other initiatives and strengthen its position not just in the industry but also in the entire Brazilian S\&T sector, Embraer partnered with the City of São José dos Campos and the São Paulo State Government to create a local technology complex (TechPark of São José dos Campos) as a key part of the strategic development plan for the metropolitan area and as a component of the state system of technology complexes (Sao Paulo Systems of Technological Parks). The technological profile of the complex enables it to meet demand mainly from the business platforms established in the city and the surrounding areas, as well as facilitating the creation of new opportunities. It is also worth noting that Embraer is installing a light structure lab in the complex (Parque Tecnológico, 2009; Simões, 2009).

The regulatory agencies set up as part of the privatization movement include ANAC (Agência Nacional de Aviação Civil), created in 2005 to regulate civil aviation and award airworthiness certification, which used to be DCTA's responsibility. DCTA's IFI now focuses on metrology and exclusively military certification (Anac, 2010).

To make its increasingly complex aircraft feasible, Embraer currently coordinates a network of strategic partners. These partners are the foundation of Embraer's value chain (as indeed in the case of all civilian aircraft makers today) and each of them in turn has its own network of suppliers (Quadros et al., 2009). As well as partners, Embraer also has direct suppliers from whom it sources lower value added goods and services.

In the beginning, Embraer was forced to deal with a large number of suppliers and bear most of the costs of development itself. These are non-recurring costs, typically requiring the sale of some 400 aircraft to cover the investment (Lima et al., 2005). Thus, the aircraft maker needs considerable credibility to persuade suppliers to become risk-sharing partners. Nowadays, modularization prevails and system and subsystem integration tasks are distributed to their respective tiers so as to enable more effective partnering and risk sharing. This is the solution Embraer has been pursuing. Table I shows the evolution of number of risk-sharing partners in the three main recent Embraer's aircraft projects.

\begin{tabular}{|l|ccccc|}
\hline Aircraft family & $\begin{array}{c}\text { Engine } \\
\text { type }\end{array}$ & $\begin{array}{c}\text { Maiden } \\
\text { flight }\end{array}$ & $\begin{array}{c}\text { No. of } \\
\text { seats }\end{array}$ & $\begin{array}{c}\text { No. of } \\
\text { suppliers }\end{array}$ & $\begin{array}{c}\text { No. of } \\
\text { risk-sharing } \\
\text { partners }\end{array}$ \\
\hline EMB 120 Brasília & Turboprop & 1991 & 30 & 500 & - \\
ERJ 135/145 & Turbofan & 1997 & $37-50$ & 350 & 4 \\
ERJ 170/190/195 & Turbofan & 2002 & $70-90-108$ & 22 & 11 \\
\hline
\end{tabular}

Table I. Evolution of Risk Partnerships in Embraer's Projects / Sources: Quadros et al. 2009; Embraer 2008. 
The process of deverticalization with partnering undertaken by Embraer thus involves integrators of systems and subsystems. In other words, in any given project Embraer develops and coordinates a network of partners and suppliers who orbit around it; engages in and encourages others to engage in strategic outsourcing and the development of capabilities; and promotes the sharing of capabilities between partners. In this sense Embraer tends to transform its partners into centrally strategic firms like itself, with a network of collaborative relationships around each one and all these networks sharing competencies (Hitt et al., 2003). Table 2 shows the evolution of the risk-sharing model in three different phases and aircraft projects.

\begin{tabular}{|ccc|}
\hline & FAMILIES & \\
\hline $1980 \mathrm{~s}$ & $1990 \mathrm{~s}$ & $2000 \mathrm{~s}$ \\
\hline 500 suppliers & 4 partners \& 350 suppliers & 16 partners \& 22 suppliers \\
\hline EMB 120 Brasília & RJ 135/145 & EMB 170/195 \\
\hline $\begin{array}{c}\text { All manufacturing by } \\
\text { Embraer }\end{array}$ & Risk-sharing partnerships & $\begin{array}{c}\text { Installation of risk-sharing partners } \\
\text { in Brazil }\end{array}$ \\
\hline $\begin{array}{c}\text { Verticalization of production } \\
\text { chain }\end{array}$ & Subcontracting of processes & $\begin{array}{c}\text { Increase in process subcontracting } \\
\text { Non-electronics design }\end{array}$ \\
\hline $\begin{array}{c}\text { Line assembly } \\
\text { Conventional production } \\
\text { processes }\end{array}$ & $\begin{array}{c}\text { Design \& electronics } \\
\text { information }\end{array}$ & $\begin{array}{c}\text { Electronic mock-up \& process } \\
\text { simulation }\end{array}$ \\
\hline $\begin{array}{c}\text { Old manufacturing } \\
\text { fabrication of parts } \\
\text { productivity }\end{array}$ & $\begin{array}{c}\text { Line assembly } \\
\text { New production concepts with improved quality \& productivity: } \\
5 S, \text { Lean, Kaizen, Cell, Robust Process }\end{array}$ \\
\hline
\end{tabular}

Table 2. Evolution of Embraer's Partnering Process/ Source: Embraer (2008)

In the ERJ 170/195 program, besides growing and deepening its partnerships Embraer also grew and diversified the participation of local suppliers, especially in engineering services and industrial processes. However, with few exceptions Embraer's network of partnerships in production and innovation remained internationalized, and the company showed no propensity to bring these activities to Brazil (Quadros et al., 2009). Indeed, Embraer is a high-tech company that has invested very little in R\&D compared with any competitor. The company typically presents itself to the market as a "creative follower" with strong design capabilities and excellent transactional competencies both in contracting with partners and in selling aircraft. Its option to build relationships with partners rather than suppliers contributes to the outsourcing of engineering and R\&D. 
Investment in R\&D by the main actors is a central aspect of any innovation system. Thus the flow of investment determines the main technological trajectories and pipelines in the system (Park \& Park, 2003). Embraer evidently got the make-or-buy decision right under the prevailing world and domestic economic, technological and contractual conditions.

Thus the key strategic decision was to outsource the most specific and least available components of an aircraft, such as fuselage, wing, propulsion, avionics and interior systems, among others. Embraer's central skill, which enables it to fill gaps from technology available elsewhere, is producing and managing contracts with its risk-taker suppliers. In fact, what is involved here is designing a foundation for the make-or-buy decision (Prahalad \& Hamel, 1990; Hamel \& Prahalad, 1995). Differently of the two archetypes of strategies discussed by Lee \& Lieberman (2007), Embraer's strategy fits in a sort of middle term between asset acquisition and internal development.

Embraer leveraged its core competencies as a specialized buyer. This involved various risks and costs, but also opportunities. For example, by developing partners as a way of reducing transaction costs (Williamson, 1985) Embraer also transferred to partners the responsibility for dealing with a great many suppliers. This in turn meant that its partners began producing ever-larger subsystems and physical sections (Quadros et al., 2009). As a result, Embraer became more dependent on these partners and vulnerable to opportunistic behavior. This risk first materialized in an episode involving the wing of the E190/195, Embraer's flagship product family. The wing was originally outsourced to Kawasaki, which on winning a contract to supply the fuselage for the Boeing 787 and not feeling able to fulfill both contracts apparently preferred to break with the Brazilian company in order to concentrate on the contract with Boeing (Reuters, 2008).

Buying from a supplier or developing and producing internally becomes a permanent decision matrix: a large part of the technology can be outsourced only when trust between the parties is strong and even so requires a minimum of internal technical competence. The important issues that cannot be overlooked in this case are the specificity of the product, process or services in question and the non-economic factors involved, i.e. factors relating to military strategy. These bring transaction costs and the role of local and national innovation systems back to the center of the analysis regarding the evolution of the Brazilian aeronautics industry.

To deal with Embraer's investment in R\&D and technological protagonism, Figure I compares investment in R\&D by the Brazilian aeronautics industry with and without Embraer. That helps measure the density of the sectoral innovation system (Central Bank of Brazil, 2009; Ministry of Science and Technology, 2009; Embraer, 2010). By excluding Embraer, it can at once be seen that government investment in R\&D directly or with the participation of other companies in the aeronautics chain is negligible. Embraer is responsible for almost all local R\&D.

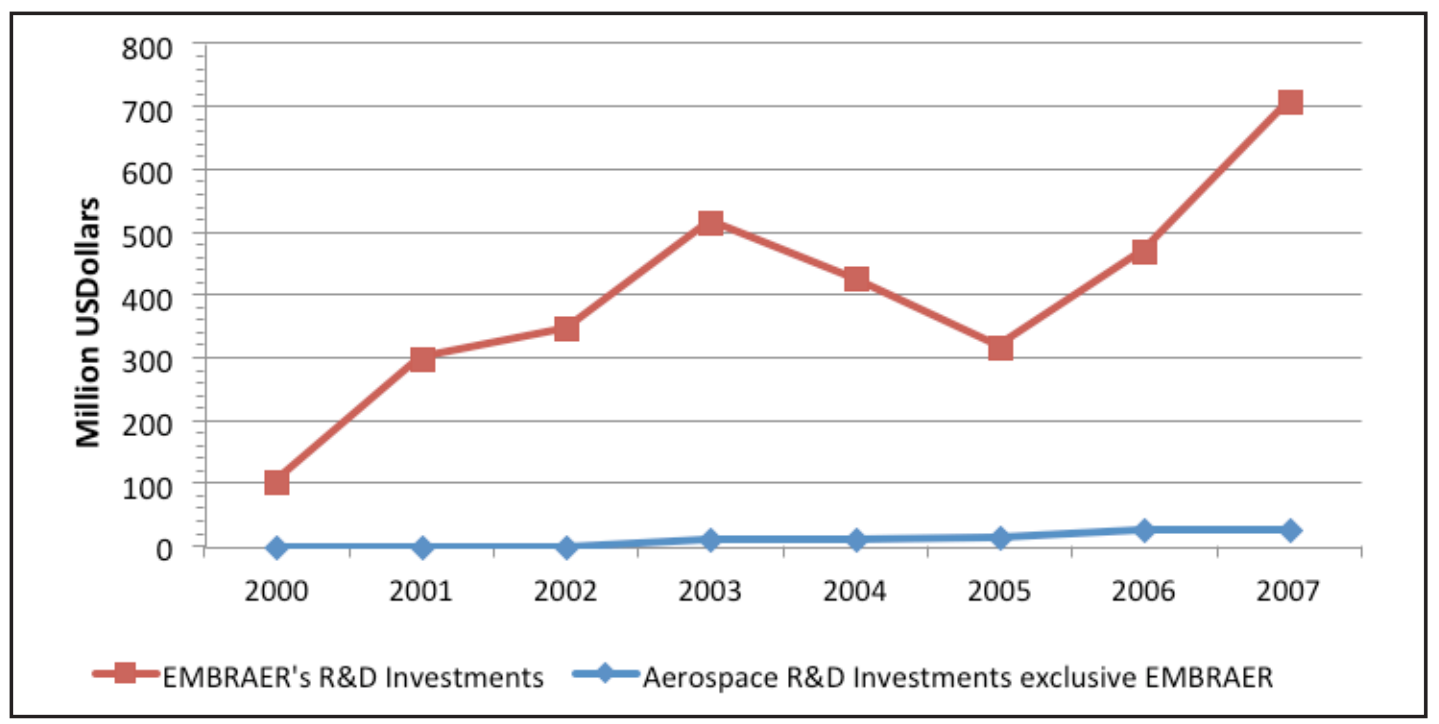

Figure I - Brazilian Aerospace R\&D Investments.

ISSN: 07I 8-2724. (http://www.jotmi.org) 


\begin{tabular}{|lcccc|}
\hline \multirow{2}{*}{ Profile } & \multicolumn{2}{c}{ Two-Aisle Long Range Jets } & \multicolumn{2}{c|}{ Single-Aisle Regional Jets } \\
\cline { 2 - 5 } & Boeing & EADS & Bombardier & Embraer \\
\hline Revenues & 61 US bi & 65 US bi & 18 US bi & 7 US bi \\
& & (Airbus 25 US bi) & \\
\hline Employees & 162.200 & (Airbus 56.000) & 66.000 & 23.500 \\
\hline R\&D & 2 US bi & 2 US bi & 200 US mi & 5 \\
\hline Patents & 2829 & 154 & & \\
(USPTO) & & & & 568 \\
\hline
\end{tabular}

Table 3 - Some Comparative Figures about Embraer Métier relative to 2007 and 2008/ Source: the authors, using data from: Quadros, 2009; Embraer, 2008; Industry Center, 2009

Embraer's R\&D investment went mainly into installation of the Light Structure Lab in the São José dos Campos TechPark. The laboratory started operating in late 2010. It is important to note that to date Embraer has not benefited from any output from this new R\&D unit.

Embraer's patenting activity began only in 2006. Up to now it can display much smaller records that its competitors. In spite of the fact that it is widely understood that patent applications plus R\&D investments are not the sole indicators of a company's R\&D performance. However, they are proxies that cannot be ignored in comparative analysis. While Embraer can be seen to have changed its R\&D strategy in recent years, stepping up investment in this area and seeking to develop proprietary technology, it will be possible only in the medium to long term to say whether this strategy will be sustained and indeed expanded. For now it is merely a trend.

Embraer is thus an exception in such a technologically dynamic and economically globalized sector. Thus we have a paradox: a weak system with a strong company. The question that naturally arises is how a firm in a typical high-tech sector can be globally competitive without these structural conditions, which in principle would appear to be a sine qua non (Fundação Museu de Tecnologia de São Paulo, 2009; Bernardes, 2000, Forjaz, 2005; Silva, 1998; Goldstein, 2002, 2008; Goldstein \& Godinho, 2010).

\section{The Brazilian AISIS and the constituent elements of a sectoral innovation system}

Returning to the elements that characterize a sectoral system, the Brazilian AISIS is analyzed below according to the seven points expounded by Malerba (2002).

As noted above, the Brazilian AISIS depends heavily on specialized technology suppliers and contractual forms of development with these suppliers that are not trivial. In this sense, the system is strongly dependent on market relations, both upstream and downstream.

The elements that characterize and support the analysis of sectoral systems, according to Malerba (2002) are: products; agents - firms and non-firms; knowledge and learning processes; basic technologies, demand, links and complementarities (centripetal movement); interaction among firms and non-firms; variation and selection processes; and surrounding institutions.

The main product of the Brazilian AISIS is evidently the aircraft produced by a company that designs, makes and sells aircraft worldwide. This is the core element of the AISIS, without which it perhaps could not be said that Brazil has an aeronautics sectoral system at all. In other sectors, by contrast, especially consumer goods, local existence of the sectoral system would not be negated 
by the absence of local production of the main product. Well-known cases include Nike and Apple, for example (Dedrick et al. 2009). There may come a time when aircraft production is entirely outsourced, but this is not foreseeable in the industry's current global trajectory.

As for the presence of firms and non-firms, as noted above the AISIS has supplier firms in Brazil and abroad, with the latter predominating as far as the value chain is concerned. The local firms are small, and supply components and parts of low relative value. As for nonfirm agents, such as educational and research institutions, several are present in Brazil but the only ones that are genuinely an active and direct part of the AISIS are the institutions that train aeronautical engineers and other professionals, and the airworthiness certification institution. Research institutions exist but are not fully integrated and contribute very little to the AISIS.

The knowledge base and learning processes have three drivers: the training of engineers; Embraer's design and integration competencies; and aeronautics certification competencies. This triangle is sufficient to constitute a system of high technological complexity. The fourth component found in the sectoral systems of all other countries with an aeronautics industry is R\&D, practically non-existent in the Brazilian case.

Interaction mechanisms between firms and non-firms in the Brazilian AISIS have a history dating from the creation of ITA and CTA. Embraer was in many ways an offspring of these organizations, as was the entire Brazilian aeronautics industry. In contrast with the U.S., European and Canadian model, however, in the Brazilian case these mechanisms are limited to the training of human resources and airworthiness certification. Military and government orders are important to other systems but it was practically absent in the recent evolution of the Brazilian AISIS.

With regard to institutions in the sense defined by Malerba (2002), such as norms, routines, regulation etc., the Brazilian AISIS has few significant locally constructed links. This may be the aspect that shows this sectoral system as one of those with the strongest institutional references. Quality and safety certification is an element that serves as a reference for any aeronautics firm anywhere in the world. The Brazilian AISIS was wise to include this component as a key competency from the word go.
Thus innovative combinations of internal and external competencies are one of the reasons for the success of this sectoral innovation system. The critical point now is prospective, i.e. to what extent this combination is sustainable in the long term and how far it will be necessary to increase local density in production and technology to assure the system's competitiveness.

International experience and known trajectories show that the path to increased density is inevitable. It is impossible to say how far density must be increased, but two facts already noted in this article suggest this direction is not just desirable but necessary: (I) the fact that the supply of technology in this sector is not regulated only by market factors and that extra-market factors, especially those of a strategic military nature, are permanent and influence access to critical technologies; (2) the fact that even in market conditions and with full access to technology, competition among firms tends to increase, leading once again to asymmetries in the supply of and access to critical technologies, now no longer for reasons of state but for market reasons. Thus the future of firms that do not produce or own knowledge and technology tends to be less sustainable than that of firms that do.

Thus what the Brazilian AISIS most lacks is more intense efforts to create and appropriate technology, not least in order to continue accessing and acquiring technology in the marketplace. Bargaining power would thereby be enhanced and fragility reduced in a context where not only competition will intensify (with China, Japan and Russia all entering the lists), but also geopolitical movement is extremely sensitive. From this perspective, the concept of sectoral innovation systems should be reinforced by that of local systems. A sectoral system is not decoupled from a territory however globalized it may be, as stressed by several authors (Saxenian, 1994; Malerba, 2003; Cassiolato \& Lastres, 2005; Quadros et al., 2000; Montoro \& Mignon, 2009; Marques \& Oliveira, 2009; Santos, 2009). 


\section{Conclusion}

Embraer's success shows that it is possible to create a globally competitive high-tech company without significant in-house R\&D and without substantially internalizing the value chain inside the company's home country. This is due to its core competencies, particularly innovating in contractual relationships with major technology suppliers, and strong design engineering capabilities. To this must be added a third competency that is no less important: the capacity to sell aircraft. However, the fragility of this model resides in the fact that its long-term competitiveness depends on external factors, especially continuity of the supply of high-density technologies with a highly specific content. In other words, it depends strongly on factors that Embraer cannot control.

The durability of partnerships such as those entered into by Embraer depends on its ability to attract and retain partners, and this ability in turn varies according to the potential gains as well as the restrictions on global trade in critical or sensitive technologies. The economic crisis has triggered a return to nationalism and restrictions in markets for prime contractors, owing to tougher rules on access to critical technology. This affects not just suppliers but also (indeed far more) the market for civilian aircraft. Moreover, the geopolitical environment is key to the long-term sustainability of the value chain governance model adopted by Embraer. Changes in this environment are frequent and unpredictable.

The absence of installed technological density and the main economic agents in the aeronautical value chain represents a far from negligible weakness for both Embraer and Brazil. Embraer will survive only if it constructs a new type of competency that enables it to participate directly in negotiations on next-generation aircraft and aeronautics technologies. This means going beyond aircraft design, assembly and marketing skills, as well as innovations in contracting out and governance, to create competencies in research and development, which in turn entails technological densification. Productive density is only an important condition when it comes with technological and knowledge density. In this perspective, and considering the specificities of the aeronautics sector, the extent on which the density of the local productive chain matters for the industry's competitiveness should depend on a preliminary strategy of expanding local capabilities and the local supply of knowledge and technology.

\section{About author}

Marcio da Silveira Luz: Researcher, Aerospace Science and Technology Department, DCTA - Brazilian Air Force Command. Background in Mechanical Engineering; Master in Aeronautical Engineering and DSc in Energy Sciences. Full Researcher at the Aerospace Science and Technology Department of the Brazilian Air Force, DCTA. Presently is Technical Adviser at the Division of Innovation Management, DGI, at the DCTA and professor of Innovation Management at the Department of Economics and Business Administration of the University of Taubaté, Unitau. Areas of interest: Planning and management of science, technology and innovation, rocketry and missiles.

Sergio Luiz Monteiro Salles-Filho: Professor, Department of Scientific and Technological Policy - University of Campinas - UNICAMP. Background in Agronomic Engineering; Master in Energy Applied to Agriculture and $\mathrm{PhD}$ in Economics. Full Professor at the Department of Science and Technology Policy of the Geosciences Institute of the University of Campinas, Unicamp. Formerly Head of Planning of the National Agency for Innovation, FINEP. Presently is Director of the School of Applied Sciences at Unicamp. Founded, in 1995, the Study Group on the Organization of Research and Innovation - GEOPI. Areas of interest: economics, planning and management of science, technology and innovation.

\section{References}

AGÊNCIA NACIONAL DE AVIAÇÃO CIVIL, ANAC, (2010). Home page, http://www.anac.gov.br/ [accessed Aug. 27, 20I0].

BERNARDES, R., (2000). O Caso Embraer - Privatização e Transformação da Gestão Empresarial: dos Imperativos Tecnológicos à Focalização no Mercado. Cadernos de Gestão Tecnológica; 46, CYTED: PGT/USP, São Paulo.

BERTAZZO, R. P., (2003). A Crise da Indústria Aeronáutica Brasileira: 1945-1968, BA Dissertation, Universidade Federal de Juiz de Fora, Instituto de Ciências Humanas e de Letras, Curso de História. 
CASSIOLATO, J. E. \& Lastres, H. M. M., (2005). Sistemas de Inovação e Desenvolvimento: as Implicações de Política. São Paulo em Perspectiva, v. 19, n. I, p. 34-45, jan./mar. 2005

CENTRAL BANK OF BRAZIL (Banco Central do Brasil BC), http://www.bcb.gov.br/ [accessed Dec. 22, 20I0]

DAGNINO, R., (1993). The Aeronautics Industry. ECIB - Studies on the Brazilian Industry Competitiveness. Technical Note IE/Unicamp/MCT/FINEP/PACDT.

DEDRICK, J., Kraemer, K. L. \& Linden, G., (2009). Who profits from innovation in global value chains?: a study of the iPod and notebook PCs. Industrial and Corporate Change, vol. 19 (I), PP 8I-116

DOSI, G (1988). The Nature of the Innovative Process. In Dosi, G, Freeman, C., Nelson, R. R., Silverberg, G. \& Soete, L. (eds.) (1988): Technical Change and Economic Theory, Pinter Publishers, London. pp 221-238.

EMBRAER, (2008). Empresa Brasileira de Aeronáutica, http://www.embraer.com.brl [accessed Oct. 28, 2008].

EMBRAER, (2010). Empresa Brasileira de Aeronáutica, http://www.embraer.com.brl [accessed Dec. 22, 20l0]. FERREIRA, M. J. B., (2009). Documento Setorial: Aeroespacial \& Defesa in Albuquerque, E. (ed.), Projeto Perspectivas do Investimento no Brasil, Bloco: Economia do Conhecimento, Sistema Produtivo: Baseado em Ciência. Rio de Janeiro: Instituto de Economia da Universidade Federal do Rio de Janeiro, UFRJ e Campinas: Instituto de Economia da Universidade Estadual de Campinas, http://www.projetopib.org/arquivos/12 ds ciencia aeroespacial_defesa.pdf [accessed Nov. 17, 20II].

FORJAZ, M. C. S., (2005). As Origens da Embraer. São Paulo: Universidade de São Paulo. Tempo Social, vol.17 no.l, pp 28I-298.

FUNDAÇÃO MUSEU DE TECNOLOGIA DE SÃO PAULO, (2009). Vencendo o Azul - a História da Indústria e Tecnologia Aeronáuticas, http://www.museutec.org. br/resgatememoria2002/old/enciclop/cap002/032.html [accessed Sep. 18, 2009].

GOLDSTEIN, A., (2002). Embraer: from national champion to global player. CEPAL Review, vol. 77, pP 97-II5, August.
GOLDSTEIN, A., (2008). A Latin American global player goes to Asia: Embraer in China. International Journal of Technology and Globalisation, vol. 4, n. I, pp. 56-69.

GOLDSTEIN, A. \& Godinho, M. M. (2010). The expansion of emerging economies' multinationals: the case of Embraer in Portugal. International Journal of Technological Learning, Innovation and Development, vol. 3, n. 3, p.p. 226 - 244

HAMEL, G. \& Prahalad, C. K., (1995). Competindo pelo Futuro. Editora Campus, Rio de Janeiro.

HITT, M. A., Ireland, R. D. \& Hoskisson, R. E. (2003). Strategic Management: Competitivity and Organization, 5th Edition. Mason, Ohio, USA: Thomson Learning/ South-Western College Publishing.

HOBDAY, M., (1998). Product Complexity, Innovation and Industrial Organisation, Research Policy, vol. 26, 1998, pp. 689-710.

HOBDAY, M.; Davies, A.; Prencipe, A. (2005). Systems Integration: a Core Capability of the Modern Corporation. Industrial and Corporate Change, 14 (6), December, 2005, Pp.II09-II43.

INDUSTRY CENTER, AEROSPACE/DEFENSE, MAJOR DIVERSIFIED, (2009). http://biz.yahoo.com/ic/40/40566. html [accessed Sep. 15, 2009].

LEE, G. K. \& Lieberman, M. B. (2010). Acquisition vs. Internal Development as Modes of Market Entry. Strategic Management Journal, 3I (2), 2010, pp I40-I58.

LIMA, J. C. C. O., Pinto, M. A. C., Migon, M. N., Montoro, G. C. F. \& Alves, M. F. (2005). A Cadeia Aeronáutica Brasileira e o Desafio da Inovação, BNDES Setorial, Rio de Janeiro, n. 2I, p. 3I-55.

LUNDVALL, B-Å. (1992). National Systems of Innovation: towards a Theory of Innovation and Interactive Learning. London, UK and Washington, USA: Pinter.

MARQUES, R. A. \& Oliveira, L. G. (2009) - Sectoral System of Innovation in Brazil: Reflections About the Accumulation of Technological Capabilities. In Malerba, F. \& Mani, S., (eds.), Sectoral Systems of Innovation and Production in Developing Countries: Actors, Structure and Evolution. Cheltenham, Glos, UK \& Northampton, Massachussets, USA: Edward Elgar Publishing Inc. 
MALERBA, F., (2002). Sectoral Systems of Innovation and Production. Research Policy, vol. 31, Issue 2, February 2002, pp. 247-264.

MALERBA, F., (2003). Sectoral Systems and Innovation and Technology Policy, Revista Brasileira de Inovação, vol. 2 (3), 2003, pp. 329-375.

MALERBA, F., (ed.), (2004). Sectoral Systems of Innovation: Concepts, Issues and Analyses of Six Major Sectors in Europe, Cambridge: Cambridge University Press.

MALERBA, F. \& Mani, S. (eds.). (2009). Sectoral Systems of Innovation and Production in Developing Countries: Actors, Structure and Evolution, Cheltenham, Glos, UK \& Northampton, Massachussets, USA: Edward Elgar Publishing Inc.

METCALFE, J.S., (1998). Evolutionary Economics and Creative Destruction. London, UK: Routledge.

MINISTRY OF SCIENCE AND TECHNOLOGY (Ministério da Ciência e Tecnologia, MCT), http://www. mct.gov.br/ [accessed Dec. 22, 20I0].

MONTORO, G. F. M. \& Migon, M. N., (eds.) (2009). Cadeia Produtiva Aeronáutica Brasileira: Oportunidades e Desafios, Banco Nacional de Desenvolvimento Econômico e Social - BNDES.

NELSON, R.R. (1990). Capitalism as an Engine of Progress. Research Policy, Volume 19, Issue 3, pages 193-2I4.

NELSON, R. R., (1994). The Co-evolution of Technology, Industrial Structure, and Supporting Institutions. Industrial and Corporate Change, Volume 3, Number I, pp. 47-63.

OECD (Organisation for Economic Co-operation and Development) (1997). National Innovation Systems.

PARK, Y. \& Park, G. (2003). When Does a National Innovation System Start to Exhibit Systemic Behavior? Industry and Innovation, volume 10, n. 4, December 2003, p. 403-4I4.

PARQUE TECNOLÓGICO DESÃOJOSÉDOS CAMPOS, home page, http://www.pqtec.org.br/ [accessed Sep. 18, 2009].
PRAHALAD, C. K. \& Hamel, G. (1990). The Core Competence of the Corporation, Harvard Business Review, vol. 68, no. 3, may-june, pp. 79-91.

QUADROS, R., Brisolla, S. Furtado, A. T. \& Bernardes, R. (2000). Força e fragilidade do sistema de inovação paulista. São Paulo em Perspectiva. 14(3) PP 124-14I.

QUADROS, R., Fleury, A., Amato, J., Nakano, D., Consoni, F., Inácio Jr, E., Cássio G. \& da Silva, C. G. (2009), Estudo da Cadeia Produtiva Aeronáutica Brasileira. In: Montoro, G. F. M. \& Migon, M. N., (eds.), Cadeia Produtiva Aeronáutica Brasileira: Oportunidades e Desafios, Banco Nacional de Desenvolvimento Econômico e Social - BNDES.

REUTERS AGENCY (2008). Global Supply Chain for Boeing's 787, http://www.reuters.com/article/CHMMFG/ idUSLB3236642008I2II [accessed Apr. 7, 2009].

SANTOS, M. M. (ed.) (2009). Estudo Prospectivo Aeronáutico, Série Cadernos da Indústria $A B D I$, Volume XIV: Brasília, ABDI - Agência Brasileira de Desenvolvimento Industrial, CGEE - Centro de Gestão e Estudos Estratégicos

SAXENIAN, A. (1994). Regional Advantages. Cambridge, Massachussets, USA: Harvard University Press.

SILVA, O. (1998). A Decolagem de um Sonho. São Paulo, SP: Lemos Editora.

SIMÕES, J. (2009). Embraer se une a IPT, ITA e Universidades para Desenvolvimento de Aviões Mais Leves e Menos Poluentes, FAPESP na Mídia, http://www. bv.fapesp.br/namidia/noticia/283/l/embraer-une-iptita-universidades/ also at TN on-line Petróleo, Apr. I, 2009, http://www.tnsustentavel.com.br/noticia/imprimir/ id/1605 [accessed Nov. 17, 20II].

WILLIAMSON, O. E. (1985). The Economic Institutions of Capitalism. The Free Press, NY; Collier Macmillan, London. 
J. Technol. Manag. Innov. 20II,Volume 6, Issue 4 